\title{
Comparative Study of Various Kinetic Models on Leaching of NCA Cathode Material
}

\author{
Soraya Ulfa Muzayanha ${ }^{1,2}$, Cornelius Satria Yudha ${ }^{1}$, Luthfi Mufidatul Hasanah ${ }^{1}$, Linggar Tungga \\ Gupita $^{1}$, Hendri Widiyandari ${ }^{3}$, and Agus Purwanto ${ }^{1, *}$
}

${ }^{1}$ Department of Chemical Engineering, Faculty of Engineering, Universitas Sebelas Maret, Jl. Ir. Sutami 36 A, Surakarta 57126, Central Java, Indonesia

${ }^{2}$ Pertamina Research \& Technology Center, PT. PERTAMINA, Jl. Raya Bekasi Km. 20, Pulogadung, Jakarta 13920, Indonesia ${ }^{3}$ Department of Physics, Faculty of Mathematic and Natural Science, Universitas Sebelas Maret, Jl. Ir. Sutami 36 A, Surakarta 57126, Central Java, Indonesia

*Corresponding author:

tel: +62-271-632112

email:aguspur@uns.ac.id

Received: September 9, 2019

Accepted: April 4, 2020

DOI: $10.22146 /$ ijc. 49412

\begin{abstract}
The kinetics study of NCA leaching in the HCl system was proposed. Various kinetic models such as shrinking core, logarithmic rate law, and Avrami equation were used to find out the most appropriate kinetic models for this process. The effect of $\mathrm{HCl}$ concentrations, leaching temperatures, solid to liquid $(S / L)$ ratio, and leaching duration were observed. The optimum conditions of NCA leaching were at HCl concentration of 4 $M$, temperature of $80^{\circ} \mathrm{C}, \mathrm{S} / \mathrm{L}$ ratio of $100 \mathrm{~g} / \mathrm{L}$, and leaching time of $1 \mathrm{~h}$. The result shows that shrinking core model with diffusion control process of residue layer describes well the leaching mechanism in this research, which is indicated by the good fitting of coefficient values of correlation $\left(R^{2}\right)$ and confirmed by the activation energy values of $\mathrm{Ni}, \mathrm{Co}, \mathrm{Al}$ that were less than $40 \mathrm{~kJ} / \mathrm{mol}$.
\end{abstract}

Keywords: NCA cathode waste; kinetics study; recycle; hydrometallurgical; Li-ion batteries

\section{- INTRODUCTION}

Nowadays, the popularity of Lithium-ion batteries (Libs) increases as a result of the high demands of Libs in portable electronics like phones, power banks, laptops, and electric vehicles. One of the most popular cathode material used for Libs is $\mathrm{Li}_{0.8} \mathrm{Co}_{0.15} \mathrm{Al}_{0.05} \mathrm{O}_{2}$ (NCA) [1]. NCA batteries have some features of high capacity and high energy density of cathode material, which is beneficial for Libs, especially for electric vehicle applications [2-3]. Due to its high demand, the usage of NCA material is predicted to increase from 2015 to 2025 [4]. As a consequence, waste such as cathode scrap or spent libs can be generated in which the recycling process is indispensable.

Hydrometallurgical is one of recycling method via leaching step using acids or base to leach out the valuable metal contained in material [5-8] which provide more advantages such as simple, low energy consumption, and high purity of product [9-10]. From our previous study, we focused on the investigation of re-synthesis NCA material via hydrometallurgical with various strong acids $\left(\mathrm{HCl}, \mathrm{HNO}_{3}, \mathrm{H}_{2} \mathrm{SO}_{4}\right)$ in the leaching system [11]. The result showed that the re-synthesis of NCA material from cathode waste has been succeeded and showed that the $\mathrm{HCl}$ leaching system is the most efficient process to recover the valuable metals in cathode waste. The recycled-NCA material had a comparable performance with commercial NCA, and it is promising to be adapted for large-scale production [11]. However, there are no reports about the study of leaching kinetics of ternary metals (nickel, cobalt, aluminum) using $\mathrm{HCl}$ from NCA waste, which is important for scaling up the production of recycled NCA.

Hence, the present novel aspect is the study of leaching kinetic from NCA scrap using $\mathrm{HCl}$. The various modeling equation is applied to predict the most appropriate modeling for kinetic study of NCA leaching. The effects of various $\mathrm{HCl}$ concentrations, temperatures, solid to liquid ratio $(\mathrm{S} / \mathrm{L})$, and leaching time were 
investigated to obtain the optimized conditions of leaching. The study of NCA waste leaching kinetics in the $\mathrm{HCl}$ system is needed considering scale up production of the recycling process.

\section{- EXPERIMENTAL SECTION}

\section{Materials}

NCA scrap used in this research was obtained from a Battery Manufacturing Facility (Sebelas Maret University, Indonesia). $\mathrm{NaOH}$ was purchased from Asahi, Cilegon, Indonesia. Analytical grade of $\mathrm{HCl}$ (Merck, Darmstadt, Germany) was used in this research.

\section{Instrumentation}

The concentration of metals was measured using Atomic Absorption Spectroscopy (AAS/PinAAcle 900T Perkin Elmer, Waltham, MA, USA). The structure and morphology of NCA before and after leaching were analyzed using X-ray Diffraction (XRD) with a $2 \theta$ range of $10-70^{\circ}$ (D2 Phaser Bruker, Germany) and Scanning Electron Microscopy (Jeol JSM-6510LA, Tokyo, Japan), respectively.

\section{Procedure}

\section{Pre-treatment}

NCA scrap still consists of Aluminum foil (Al foil), binder (Polyvinylidene Difluoride/PVDF), conducting agent (Acetylene Black/AB), and active material contained valuable metals. $\mathrm{NaOH}$ dissolution was employed to separate the powder from $\mathrm{Al}$ foil. First, the collected $50 \mathrm{~g}$ of NCA scrap was cut into smaller size and then immersed with agitation in $200 \mathrm{~mL}$ of $5 \mathrm{M} \mathrm{NaOH}$ solution for $2 \mathrm{~h}$. The $\mathrm{Al}$ foil reacted spontaneously with $\mathrm{NaOH}$ solution to form sodium aluminate then the powder can be detached from $\mathrm{Al}$ foil. The slurry was filtered to obtain the powder, which will be washed using demineralized water to eliminate the remaining $\mathrm{NaOH}$ during the dissolution process. The collected powder was heated in an oven at a temperature of $80{ }^{\circ} \mathrm{C}$. Then, the PVDF and $A B$ were burned via heat treatment at a temperature of $800{ }^{\circ} \mathrm{C}$ for $4 \mathrm{~h}$. The powder was then minimized by grounding into smaller sizes to enhance the surface area of powder, which can be beneficial during the leaching process.

\section{Leaching process}

Determination of the optimum conditions. The leaching process was conducted in a $500 \mathrm{~mL}$ threenecked batch reactor of Pyrex involving a water bath to maintain the specified temperature. The leaching conditions were performed at $\mathrm{HCl}$. The leachate was then filtered to separate the filtrate from the residue. In order to find out the total concentrations of valuable metals $(\mathrm{Ni}, \mathrm{Co}, \mathrm{Al})$, the powder was completely leached out in concentrated $\mathrm{HCl}$. The filtrate was analyzed using Atomic Absorption Spectroscopy (AAS) to determine the concentrations of metals. The effect of acid concentrations, various temperatures, solid to liquid ratio $(\mathrm{S} / \mathrm{L}$ ratio), and time of leaching were observed to find out the optimized conditions in this leaching process. The leaching efficiency was calculated using Eq. (1):

$\mathrm{X}=\frac{\mathrm{Ct}-\mathrm{C}}{\mathrm{Ct}} \times 100 \%$

where $\mathrm{X}$ is leaching efficiency of $\mathrm{Ni}, \mathrm{Co}, \mathrm{Al}(\%), \mathrm{Ct}$ is the total concentration of $\mathrm{Ni}, \mathrm{Co}, \mathrm{Al}(\mathrm{g} / \mathrm{L})$, and $\mathrm{C}$ is the concentration of $\mathrm{Ni}, \mathrm{Co}, \mathrm{Al}$ at certain conditions $(\mathrm{g} / \mathrm{L})$.

Kinetics. The shrinking core model, logarithmic rate law, and Avrami equation were studied to elucidate the suitable leaching kinetics during the process.

\section{Characterization of NCA waste before and after leaching}

The NCA powder before leaching and the residue of the leaching were analyzed using X-ray Diffraction (XRD) to investigate the structure of NCA before and after the leaching process. Scanning Electron Microscopy (SEM) was also employed to observe the morphology of NCA waste.

\section{- RESULTS AND DISCUSSION}

\section{Leaching Process}

$\mathrm{HCl}$ was used as a leaching agent during the leaching process. In order to evaluate the optimum conditions of the leaching process using $\mathrm{HCl}$ for recycling of NCA scrap, the various conditions of $\mathrm{HCl}$ concentrations, leaching time, S/L ratio, and temperatures during leaching were shown in Fig. 1. As shown in Fig. 1(a), the leaching efficiency of Ni, Co, Al increased up to concentrations of $3 \mathrm{M}$ and tended to be 

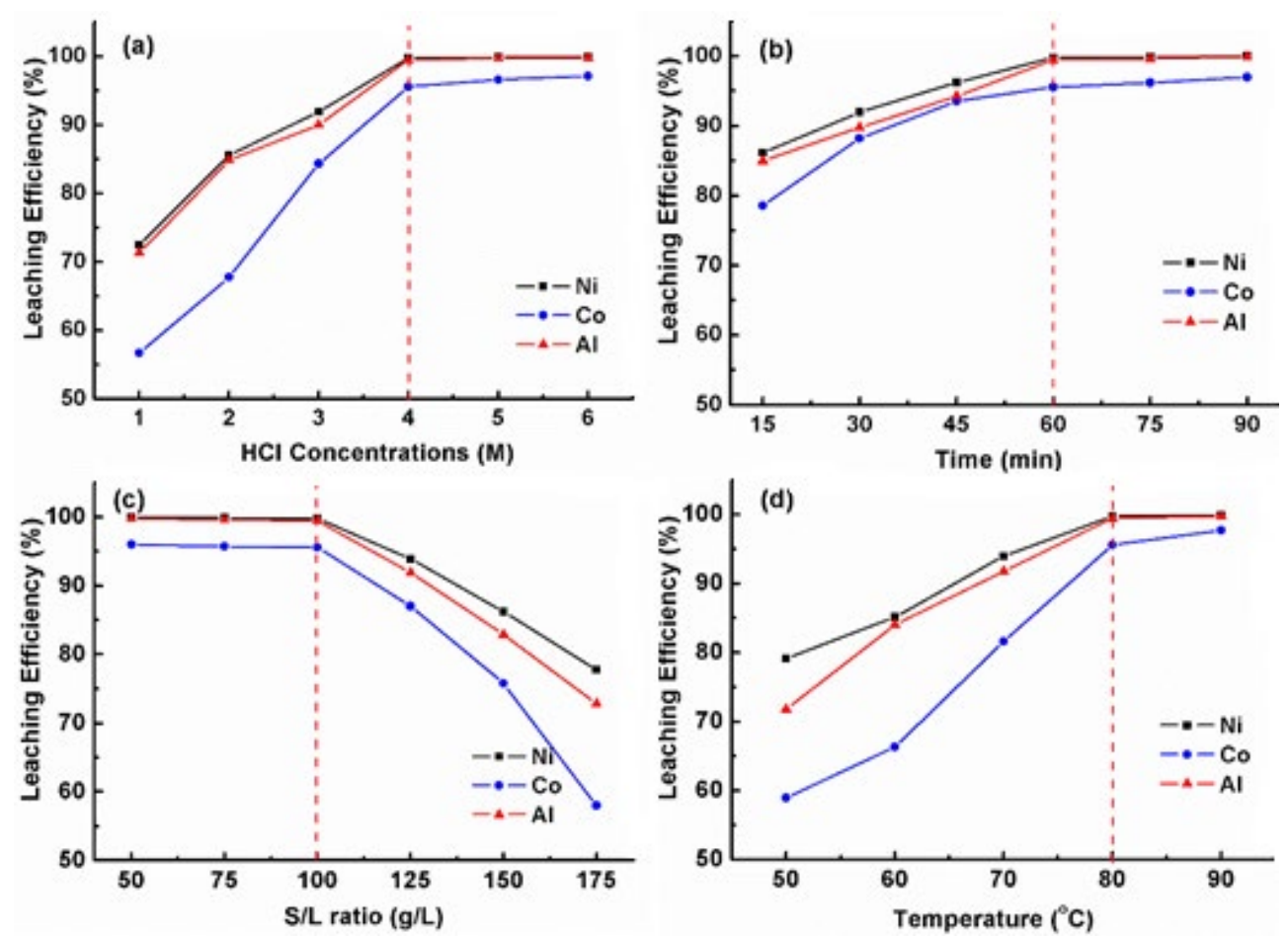

Fig 1. Effect of (a) $\mathrm{HCl}$ concentrations, (b) leaching duration, (c) S/L ratio, and (d) temperatures on NCA waste leaching

constant from $4 \mathrm{M}$ to $6 \mathrm{M}$. The increasing concentrations of $\mathrm{HCl}$ from $5 \mathrm{M}$ to $6 \mathrm{M}$ did not present a significant effect on leaching efficiencies after $60 \mathrm{~min}$. It means that a continued increase in acid concentrations can impede the diffusion of metal ion and inhibit the reaction during the leaching process [12]. Therefore, the acid concentration of $4 \mathrm{M}$ was selected.

Fig. 1(b) presents the effect of reaction time (15$75 \mathrm{~min}$ ) on the leaching efficiencies of $\mathrm{Ni}, \mathrm{Co}$, and $\mathrm{Al}$ at $100 \mathrm{~g} / \mathrm{L} \mathrm{S} / \mathrm{L}$ ratio, $80^{\circ} \mathrm{C}$. At high temperatures, the reaction between metals and $\mathrm{HCl}$ was rapid. As a result, the leaching efficiencies enhanced slightly with time. However, the leaching efficiencies of $\mathrm{Ni}, \mathrm{Co}$, and $\mathrm{Al}$ increased with the increasing duration of the reaction. Fig. 1(c) shows the effect of $\mathrm{S} / \mathrm{L}$ ratio $(\mathrm{g} / \mathrm{L})$ towards the leaching efficiencies of $\mathrm{Ni}, \mathrm{Co}$, Al. There was an insignificant difference in leaching efficiencies from $50 \mathrm{~g} / \mathrm{L}$ to $100 \mathrm{~g} / \mathrm{L}$. Still, the increasing of S/L ratio after $100 \mathrm{~g} / \mathrm{L}$ lead to the leaching efficiencies of metal ions decreases. It can be caused by the higher S/L ratio lead to a more viscous solution that can slow the reaction during leaching and resulted in low efficiency [12]. Next, the effects of leaching temperature are shown in Fig. 1(d). It can be seen that leaching temperature from $50-70^{\circ} \mathrm{C}$ has a significant impact on the leaching efficiencies of $\mathrm{Ni}$, $\mathrm{Co}$, and $\mathrm{Al}$, but tends to constant after $80^{\circ} \mathrm{C}$. This high temperature $\left(80^{\circ} \mathrm{C}\right)$ increases the reactivity of metal ions, which promote reaction acceleration during leaching [12]. However, a further increase in temperature $\left(90^{\circ} \mathrm{C}\right)$ resulted in the leaching efficiency near to the temperature of $80^{\circ} \mathrm{C}$. Also, it was difficult to control the leaching system at a temperature of $90^{\circ} \mathrm{C}$. Consequently, the temperature of $80^{\circ} \mathrm{C}$ was selected. Therefore, the optimum leaching conditions in this study were chosen at the concentration of $4 \mathrm{M} \mathrm{HCl}$, temperature of $80^{\circ} \mathrm{C}, \mathrm{S} / \mathrm{L}$ ratio of $100 \mathrm{~g} / \mathrm{L}$, and leaching time of $60 \mathrm{~min}$.

Fig. 2 presents the leaching behavior at the optimum conditions of leaching. The result shows that the rapid reaction during the leaching process occurred at the beginning (0-15 $\mathrm{min})$, then the reaction became slow, which is indicated from the curve that tends to be constant. The reactivity of $\mathrm{HCl}$ towards metals is very high, as reported in the previous study [11]. The metal oxides are converted from trivalent to divalent states of $\mathrm{Ni}$ and Co during reaction on the leaching process [11]. 


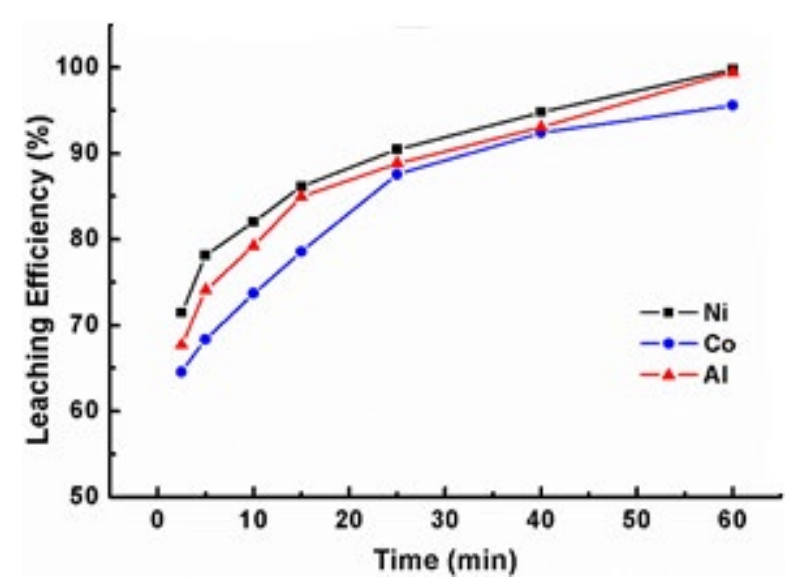

Fig 2. Leaching behavior of $\mathrm{Ni}, \mathrm{Co}, \mathrm{Al}$ at optimum condition

The reaction occurred during the leaching process between $\mathrm{HCl}$ and NCA scrap is explained in Eq. 2 [11].

$$
\begin{aligned}
& 3 \mathrm{HCl}_{(\mathrm{aq})}+\mathrm{LiNi}_{0.80} \mathrm{Co}_{0.15} \mathrm{Al}_{0.05} \mathrm{O}_{2(\mathrm{~s})} \rightleftarrows \mathrm{LiCl}_{(\mathrm{aq})} \\
& +0.8 \mathrm{NiCl}_{2(\mathrm{aq})}+0.15 \mathrm{CoCl}_{2(\mathrm{aq})}+0.05 \mathrm{AlCl}_{3(\mathrm{aq})} \\
& +1.5 \mathrm{H}_{2} \mathrm{O}_{(\text {liq })}+0.5 \mathrm{O}_{2(\mathrm{~g})}
\end{aligned}
$$

\section{The Kinetics Study of Leaching}

In this study, the leaching process involves the reaction between NCA and $\mathrm{HCl}$ as a solid phase and liquid phase, respectively. The leaching kinetic models possible occurred are shrinking core, logarithmic rate law, and Avrami equation. The equations of leaching kinetic were presented below [12-13]:

Shrinking core model

$\mathrm{X}=\mathrm{k} . \mathrm{t}$

$1-(1-\mathrm{X})^{1 / 3}=\mathrm{k} . \mathrm{t}$

$1-\frac{2}{3} \mathrm{X}-(1-\mathrm{X})^{2 / 3}=\mathrm{k} \cdot \mathrm{t}$

Logarithmic rate law

$(-\ln (1-\mathrm{X}))^{2}=\mathrm{k.t}$

Avrami equation

$\ln (-\ln (1-\mathrm{X}))=\ln \mathrm{k}+\mathrm{n} \ln \mathrm{t}$

In Eq. (3-7), $\mathrm{X}$ is the efficiency of leaching, $\mathrm{k}$ is the constant in the reaction rate $(1 / \mathrm{min}$ for Eq. (3-4) and $1 /\left(\min ^{\mathrm{n}}\right)$ for Eq. $\left.(7)\right)$ that is the slope of the plotted line, $t$ is the time required for the leaching process $(\mathrm{min})$. The activation energy of leaching using $\mathrm{HCl}$ can be calculated by the Arrhenius equation that presents the relationships between temperature and $\mathrm{k}$ value. The Arrhenius equation is shown in Eq. (8).

$\mathrm{k}=\mathrm{Ae}^{-\mathrm{Ea} / \mathrm{RT}}$

where, k: Kinetic constant rate, 1/min; A: Frequency factor, 1/min; Ea: Activation energy, J/mol; R: Gas constant, $(8.3145 \mathrm{~J} / \mathrm{mol} \mathrm{K})$.

\section{Shrinking core}

The first prediction of leaching kinetic models in this study was the shrinking core model. The kinetic models for a shrinking core feature several forms of control: mass transfer process control of the liquid layer (Eq. 3), chemical reaction process control of the surface (Eq. 4), and diffusion process control of the residue layer (Eq. 5) [14].

Shrinking core Eq. (3): $\mathbf{X}=$ k.t. In this kinetic equation of the shrinking core model, the leaching process is controlled by the mass transfer process of the liquid layer. The plotted of $\mathrm{X}$ vs. $\mathrm{t}$ and $\mathrm{Ea}$ for $\mathrm{Ni}, \mathrm{Co}, \mathrm{Al}$, respectively, is shown in Fig. 3(a-c). Some of the coefficient values of correlation $\left(\mathrm{R}^{2}\right)$ for each metal are below 0.95 , which indicated poor fitting of this equation.

In this study, due to the high temperature and $\mathrm{HCl}$ concentration of leaching conditions, the high solubility of the metal ions that lead to rapid release into the bulk solution occurred. Also, the high speed of stirring (800 rpm) was used. Thus, the mass transfer process runs fast and can be ignored, according to the results of $\mathrm{R}^{2}$ values in the curves [12].

Shrinking core Eq. (4): $1-(1-X)^{1 / 3}=$ k.t . Previously, this kinetic model was successfully applied in the recycling of mixed spent Libs [15]. In this equation, the leaching process is controlled by the chemical reaction process of the surface. The kinetic and $\mathrm{Ea}$ curves of $\mathrm{Ni}$, $\mathrm{Co}$, and $\mathrm{Al}$ in this study are presented in Fig. 4. However, the $\mathrm{R}^{2}$ values of each curve have a low fitting degree $(<$ 0.95 ). This may be caused by the high reactivity of $\mathrm{HCl}$ towards metal oxide during leaching, resulting in fast reaction kinetics. As a consequence, the chemical reaction process of the surface can be negligible in this study. 

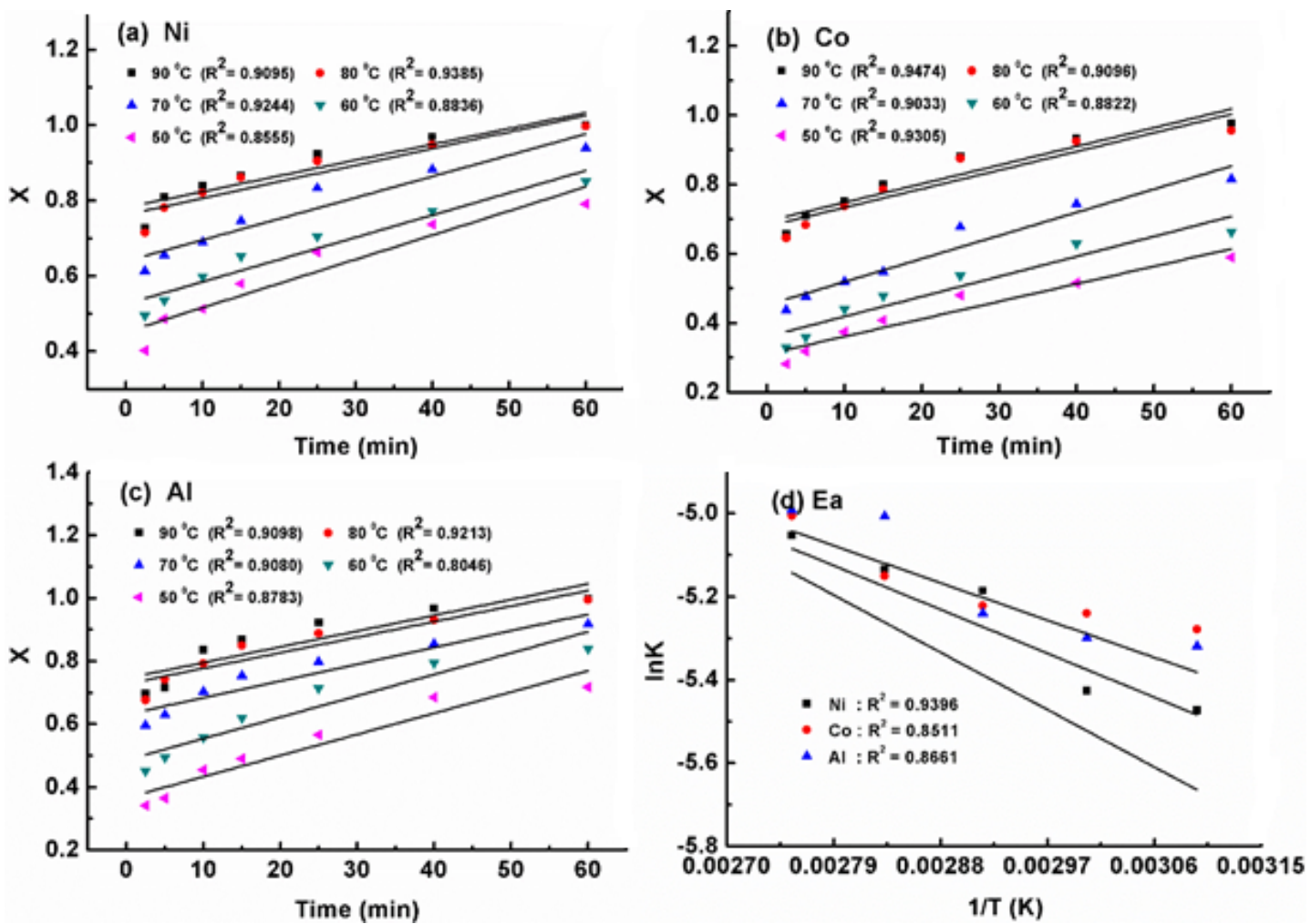

Fig 3. The kinetic curve of (a) Ni, (b) Co, and (c) Al using shrinking core (Eq. 3). (d) the Arrhenius plot of Ni, Co, $\mathrm{Al}$ using shrinking core (Eq. 3)
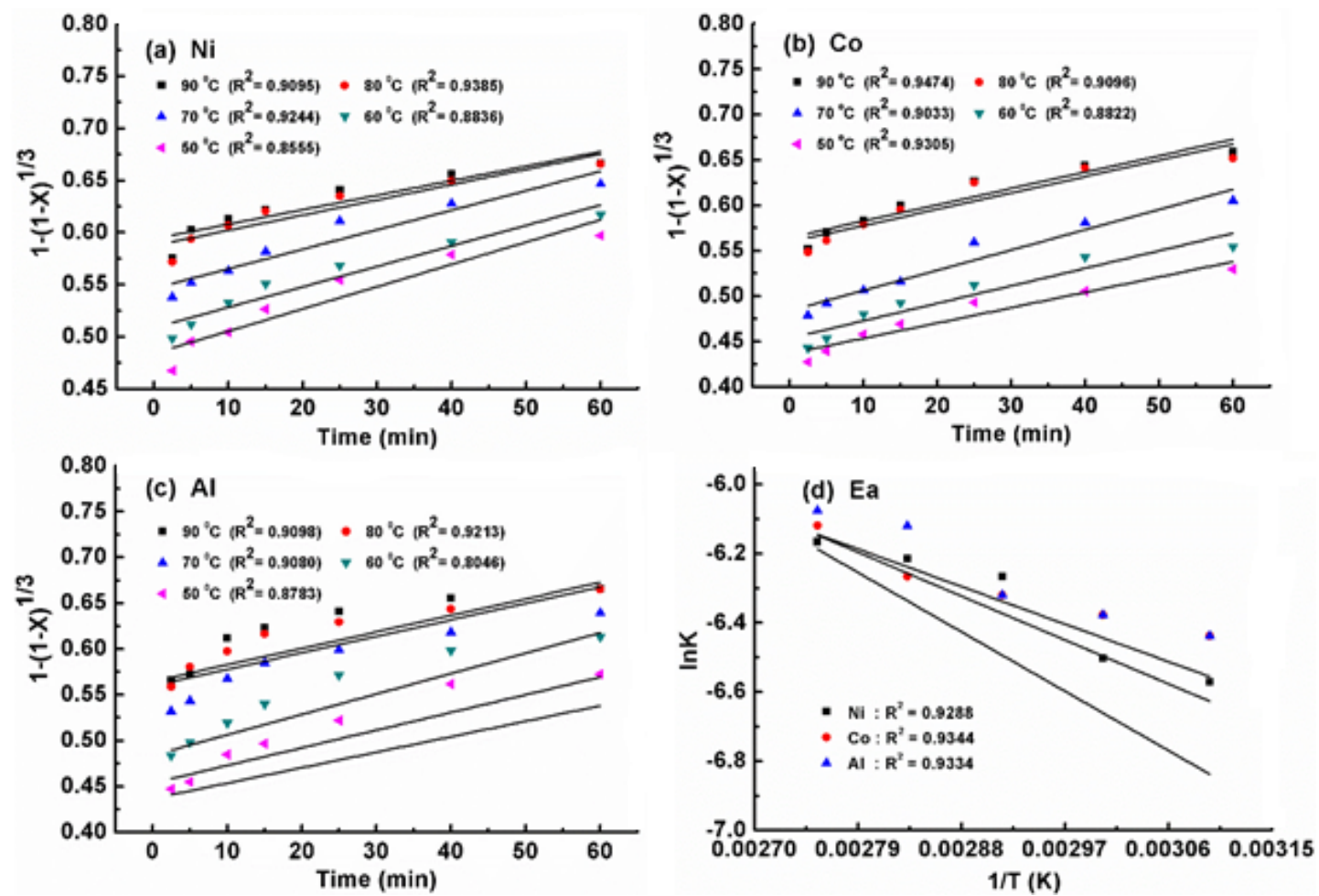

Fig 4. The kinetic curve of (a) Ni, (b) Co, and (c) Al using shrinking core (Eq. 4). (d) the Arrhenius plot of Ni, Co, $\mathrm{Al}$ using shrinking core (Eq. 4 ) 
Shrinking core Eq. (5): $1-\frac{2}{3} X-(1-X)^{2 / 3}=k . t$. The last shrinking core model is controlled by the diffusion process of the residue layer and has been applied successfully in the previous study $[14,16]$. Fig. 5 represents the curves of the kinetic equation and $\mathrm{Ea}$ of $\mathrm{Ni}$, $\mathrm{Al}$, and Al. All curves have high values of $\mathrm{R}^{2}(>0.95)$, suggesting a high fitting degree of this kinetic model.

\section{Logarithmic rate law}

Another kinetic model for the leaching process is the logarithmic rate law model. Based on our previous study, the logarithmic rate law was successfully applied for the leaching process of valuable metals [17-20]. In this study, the plots of the logarithmic rate law model (Eq. (6)) are shown in Fig. 6 . The curves exhibit a poor fitting of $\mathrm{R}^{2}$ values $(<0.95)$. Chen et al. have selected this kinetic model due to the difference in leaching behaviors of valuable metals ( $\mathrm{Li}$ and $\mathrm{Co}$ ) [17]. In this case, the leaching behaviors of $\mathrm{Ni}, \mathrm{Co}$, and $\mathrm{Al}$ are similar (see Fig. 2); therefore, this kinetic equation is irrelevant to this study.

\section{Avrami model}

Kinetic equation related to leaching phenomena is the Avrami model. During the $\mathrm{HCl}$ leaching process, the NCA waste was nearly dissolved in $\mathrm{HCl}$ without the formation of a solid phase, which is the opposite of the crystallization process. Zhuang et al. have used this equation for the recycling process of $\mathrm{LiNi}_{0.5} \mathrm{Co}_{0.2} \mathrm{Mn}_{0.3} \mathrm{O}_{2}$ using mixed acids of phosphoric and citric acids [21]. Other researchers reported that the Avrami equation had been succeeded in explaining the leaching kinetics of multi-metals [22-24]. Thus, the implementation of the Avrami model is appropriate to be used in this study.

The curves of using the Avrami equation (Eq. 7) for $\mathrm{Ni}, \mathrm{Co}$, and $\mathrm{Al}$ are shown in Fig. 7. The $\mathrm{R}^{2}$ values are less than 0.95 , which indicates the invalid fitting by this equation. The result showed that the value of $n$, which suggests the leaching behavior of metals, is obtained to be around 0.3-0.46. In our previous study [21], we have found that the leaching reaction initially occurred rapidly after several minutes, and then the reaction starts
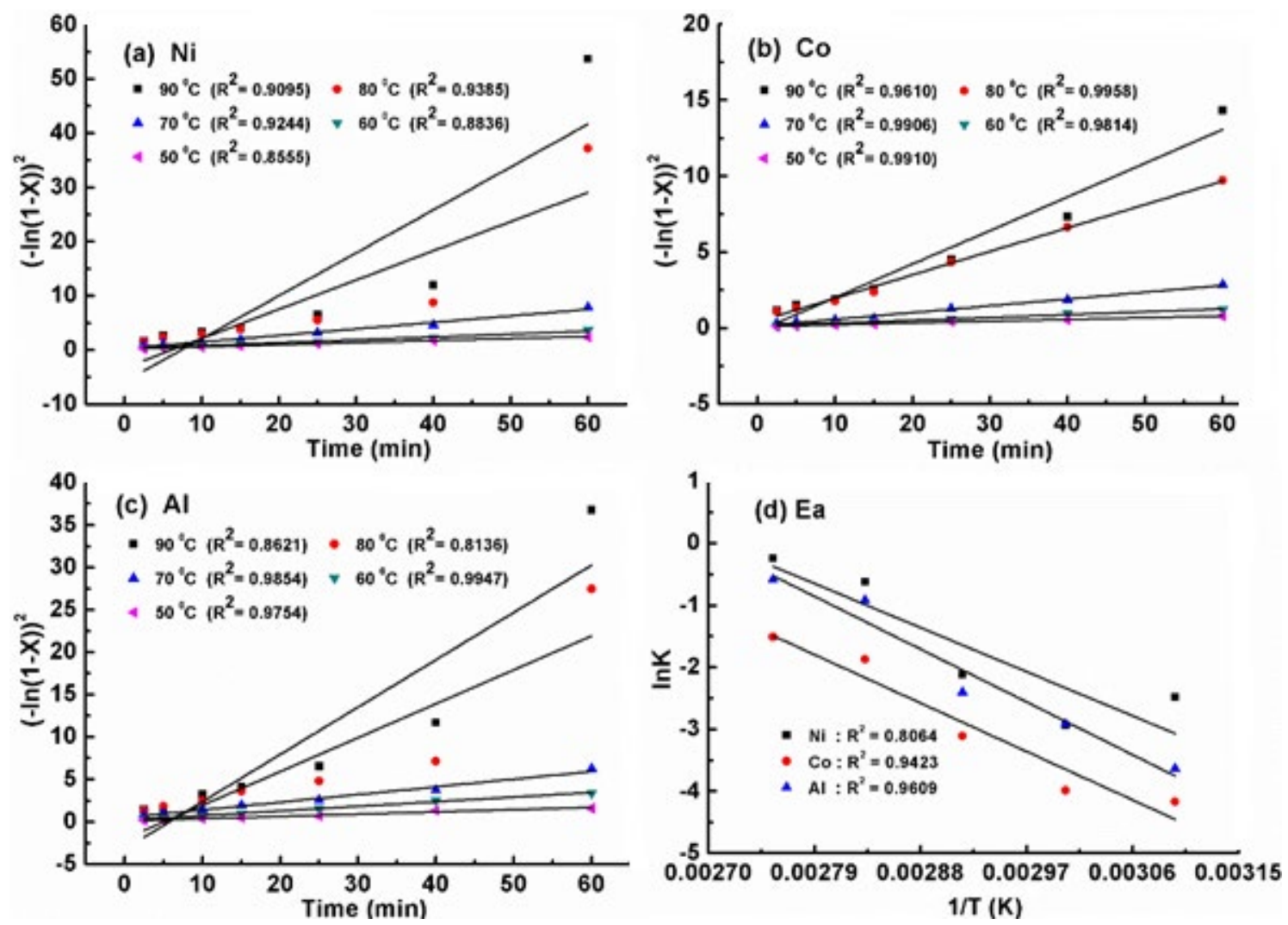

Fig 6. The kinetic curve of (a) Ni, (b) Co, and (c) Al using logarithmic rate law (Eq. 6). (d) the Arrhenius plot of Ni, $\mathrm{Co}$, and $\mathrm{Al}$ using logarithmic rate law (Eq. 6) 

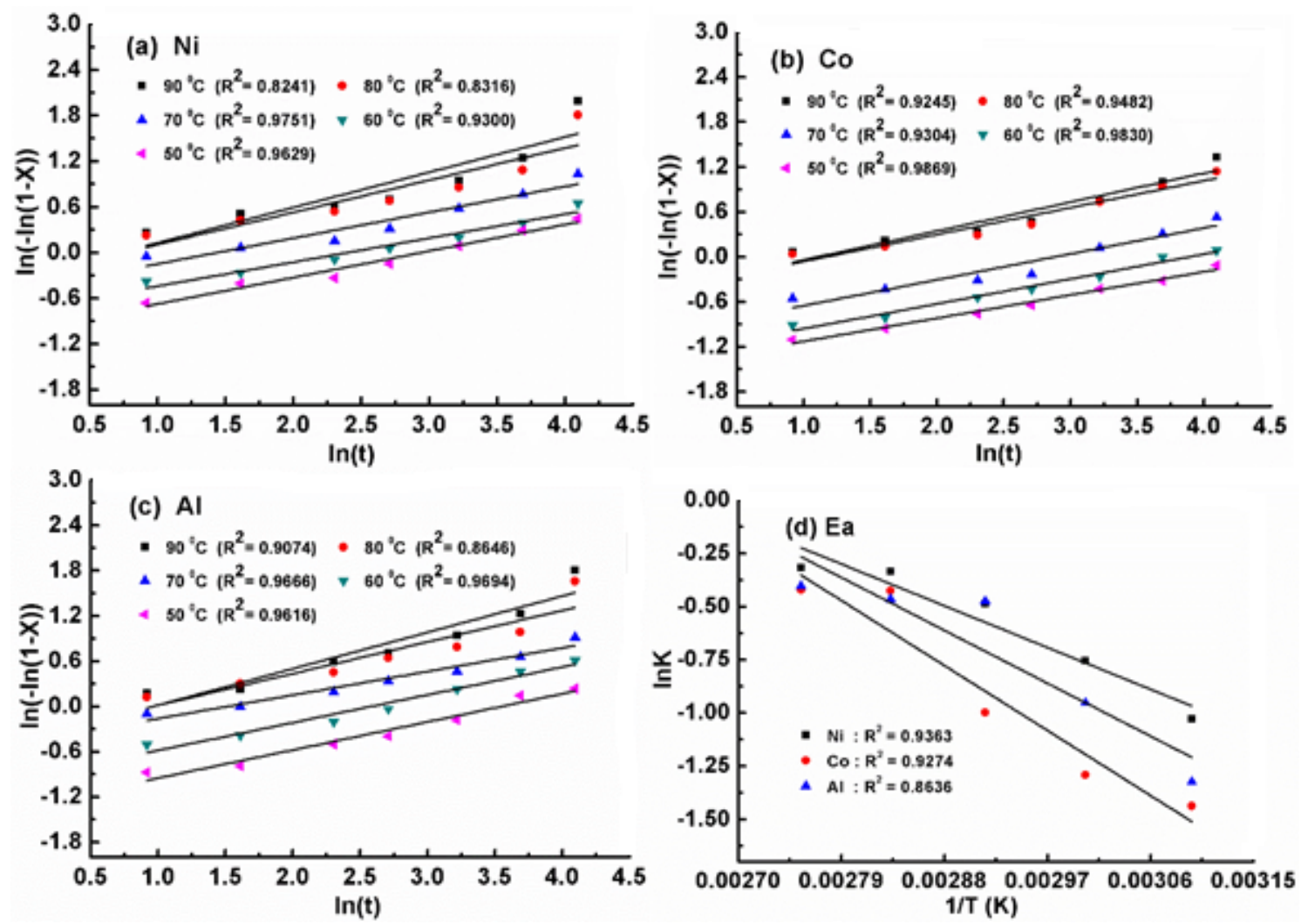

Fig 7. The kinetic curve of (a) Ni, (b) Co, and (c) Al using the Avrami model (Eq. 7). (d) the Arrhenius plot of Ni, Co, and $\mathrm{Al}$ using the Avrami model (Eq. 7)

to slow down. Based on previous studies, the value of $\mathrm{n}$ is in the range of $0.5-1$ [21]. Therefore, it is predicted that the leaching mechanism in this study does not behave like the reverse crystallization mechanism proposed by the Avrami model.

The summary of the activation energy calculation proposed by shrinking core, logarithmic rate law, and Avrami equation was presented in Table 1. The result exhibits that the most appropriate kinetics model of the $\mathrm{HCl}$ leaching process for NCA waste was the shrinking core, where the diffusion process is controlled by the residue layer (Eq. 3). From Table 1, it is marked that all curves of shrinking core Eq. (5) show good fitting lines higher than 0.95 . Also, the results of activation energy (Ea) for $\mathrm{Ni}, \mathrm{Co}$, and $\mathrm{Al}$ were 21.75, 38.09, and $26.07 \mathrm{~kJ} / \mathrm{mol}$, respectively. The Ea values of all metals were lower than $40 \mathrm{~kJ} / \mathrm{mol}$, confirmed that the leaching step was controlled by the diffusion process of the residue layer [25-26]. In this study, the $\mathrm{Ea}$ of $\mathrm{Ni}$ had the lowest value than $\mathrm{Co}$ and $\mathrm{Al}$, indicating that the extraction process of $\mathrm{Ni}$ is easier than other metal, which is consistent with the leaching behavior in Fig. (2-5) [14].

Table 1. Summary of activation energy from various kinetic equations

\begin{tabular}{|c|c|c|c|c|c|c|c|c|c|c|}
\hline \multirow{3}{*}{ Metals } & \multicolumn{10}{|c|}{$\mathrm{Ea}(\mathrm{kJ} / \mathrm{mol})$} \\
\hline & \multicolumn{2}{|c|}{$\begin{array}{c}\text { Shrinking Core } \\
\text { Eq. (3) }\end{array}$} & \multicolumn{2}{|c|}{$\begin{array}{c}\text { Shrinking Core } \\
\text { Eq. (4) }\end{array}$} & \multicolumn{2}{|c|}{$\begin{array}{c}\text { Shrinking Core } \\
\text { Eq. (5) }\end{array}$} & \multicolumn{2}{|c|}{$\begin{array}{c}\text { Logarithmic Rate } \\
\text { Law }\end{array}$} & \multicolumn{2}{|c|}{ Avrami Equation } \\
\hline & value & $\mathrm{R}^{2}$ & value & $\mathrm{R}^{2}$ & value & $\mathrm{R}^{2}$ & value & $\mathrm{R}^{2}$ & value & $\mathrm{R}^{2}$ \\
\hline $\mathrm{Ni}$ & 11.0915 & 0.9495 & 10.7640 & 0.9288 & 21.7549 & 0.9569 & 65.7386 & 0.8064 & 18.1406 & 0.9363 \\
\hline Co & 6.1195 & 0.9121 & 7.2413 & 0.9344 & 38.0962 & 0.9751 & 72.1931 & 0.9423 & 28.2402 & 0.9274 \\
\hline $\mathrm{Al}$ & 9.1792 & 0.8745 & 9.5450 & 0.9334 & 26.0726 & 0.9642 & 78.7092 & 0.9609 & 22.9780 & 0.8636 \\
\hline
\end{tabular}




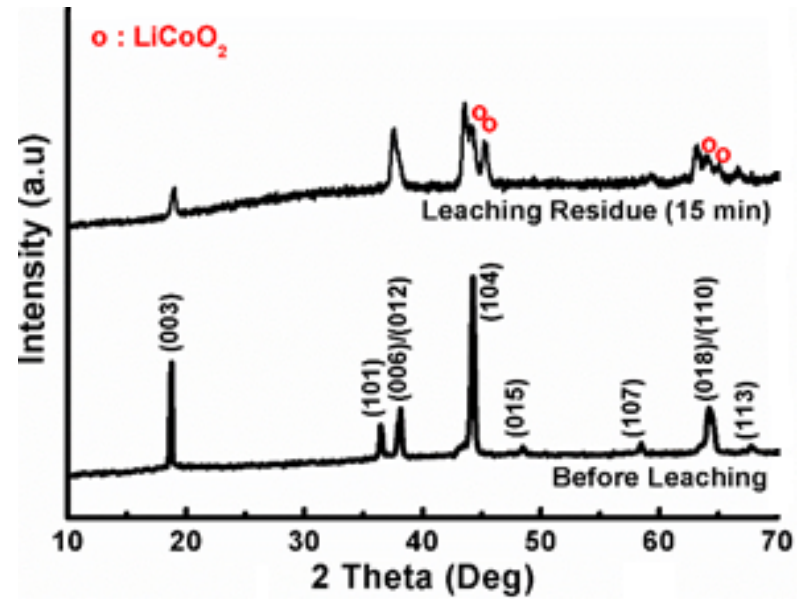

Fig 8. XRD patterns of NCA waste before and after leaching for $15 \mathrm{~min}$

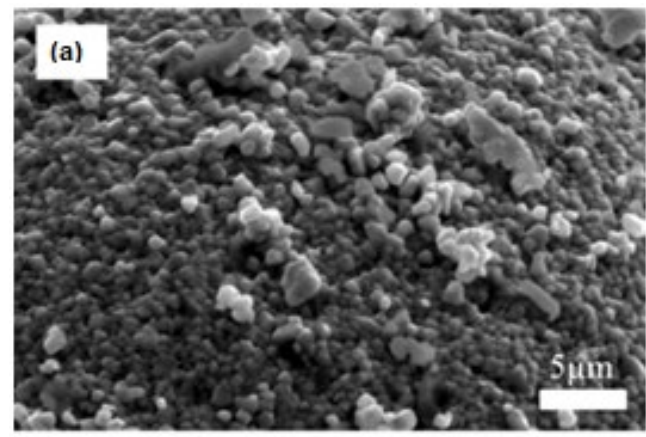

Fig 9. SEM images of NCA waste (a) before and (b) after leaching for $15 \mathrm{~min}$

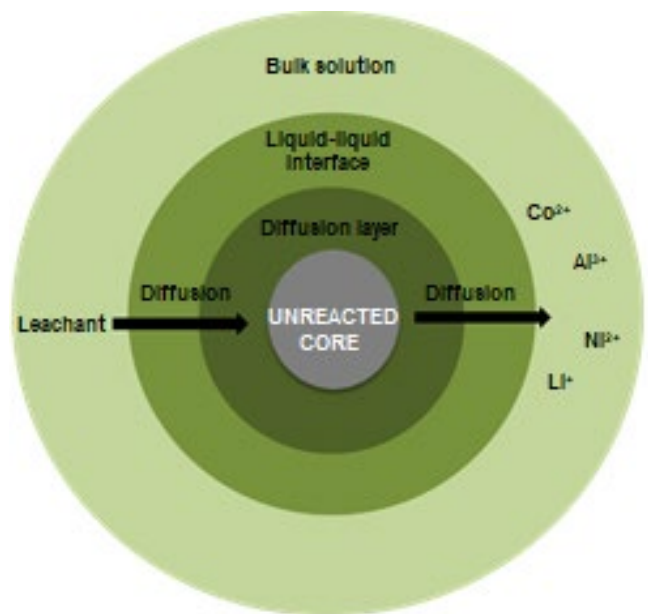

Fig 10. The mechanism of the leaching process using a shrinking core model

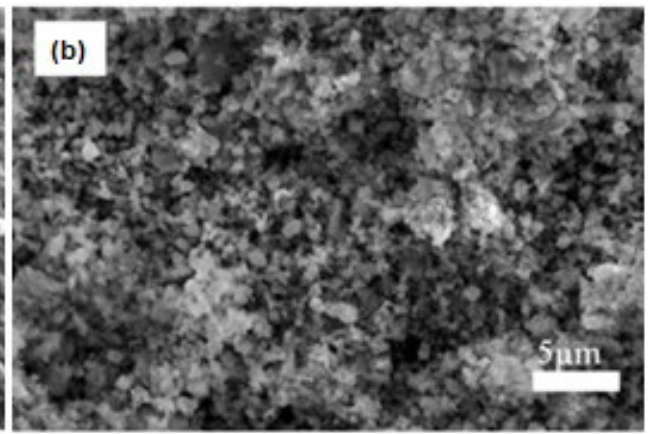

\section{Material Characterization Before and After Leaching}

The comparison of XRD patterns between powder before and after leaching of $15 \mathrm{~min}$ is shown in Fig. 8. The XRD patterns of samples exhibit the structure of hexagonal $\alpha-\mathrm{NaFeO}_{2}$ with space group $\mathrm{R} 3 \mathrm{~m}$. There is no other crystalline chemical detected, indicating that only the dissolution of metals has occurred and no precipitates form during the leaching process [21]. However, the $\mathrm{LiCoO}_{2}$ phase found on the peaks of (104) and (018)/(110) suggests that the reduction of Co occurs during leaching [20].

The morphology of NCA waste before and after leaching ( $15 \mathrm{~min})$ is shown in Fig. 9. It can be seen that the morphology of leaching residue is more amorphous due to the dissolution of the metal. Moreover, the loose particles originate from dense spherical particles which confirm the shrinking core phenomena due to acid leaching. The mechanism of the leaching process using a shrinking core model in Fig. 10 is following these steps: $1^{\text {st }}$ step: The diffusion process of leachant molecules from the bulk solution to the liquid-liquid interface.

$2^{\text {nd }}$ step: The diffusion process whereby molecules are leached from the liquid-liquid interface via the diffusion layer to the unreacted core surface.

$3^{\text {rd }}$ step: The reaction between leachant molecules and the solid core at the solid-liquid interface. The metal ions are dissolved and released into the bulk solution.

$4^{\text {th }}$ step: The process of diffusing metal ions via the diffusion layer into the liquid-liquid interface.

$5^{\text {th }}$ step: The process of the diffusion of metal ions into the bulk solution.

\section{- CONCLUSION}

This study focused on the optimization and kinetic study of the NCA leaching process using $\mathrm{HCl}$. The 
optimum condition of leaching was at $4 \mathrm{M} \mathrm{HCl}$ concentration, $80^{\circ} \mathrm{C}, \mathrm{S} / \mathrm{L}$ ratio of $100 \mathrm{~g} / \mathrm{L}$ for $1 \mathrm{~h}$. Various kinetic equation models were plotted to determine the suitable kinetic model in this study. The shrinking core model with diffusion process control of the residue layer could describe well the leaching mechanism and exhibited a good fitting line on the curve with $\mathrm{R}^{2}$ higher than 0.95 . The activation energy of this process was higher than $40 \mathrm{~kJ} / \mathrm{mol}$, which reveals that the leaching process was controlled by the residue layer.

\section{- ACKNOWLEDGMENTS}

This paper is funded by Indonesia Endowment Fund for Education (LPDP/Lembaga Pengelola Dana Pendidikan) through Pendanaan Riset Inovatif Produk (Rispro) Invitasi grant no.PRJ-31/LPDP/2018 and supported by the Indonesian Ministry of Research, Technology, and Higher Education under the WCU program managed by Institut Teknologi Bandung (ITB).

\section{- REFERENCES}

[1] Purwanto, A., Yudha, C.S., Ubaidillah, U., Widiyandari, H., Ogi, T., and Haerudin, H., 2018, NCA cathode material: Synthesis methods and performance enhancement efforts, Mater. Res. Express, 5 (12), 122001.

[2] Nitta, N., Wu, F., Lee, J.T., and Yushin, G., 2015, Liion battery materials: Present and future, Mater. Today, 18 (5), 252-264.

[3] Yudha, C.S., Muzayanha, S.U., Widiyandari, H., Iskandar, F., Sutopo, W., and Purwanto, A., 2019, Synthesis of $\mathrm{LiNi}_{0.85} \mathrm{Co}_{0.14} \mathrm{Al}_{0.01} \mathrm{O}_{2}$ cathode material and its performance in an $\mathrm{NCA}$ /graphite full-battery, Energies, 12, 1886.

[4] Pillot, C., 2017, Lithium-ion battery raw material Supply \& demand 2016-2025, Avicenne Energy, Information for Growth, Mainz, Germany, 30 January 2017.

[5] Li, L., Dunn, J.B., Zhang, X.X., Gaines, L., Chen, R.J., Wu, F., and Amine, K., 2013, Recovery of metals from spent lithium-ion batteries with organic acids as leaching reagents and environmental assessment, J. Power Sources, 233, 180-189.
[6] Zheng, X., Gao, W., Zhang, X., He, M., Lin, X., Cao, H., Zhang, Y., and Sun, Z., 2017, Spent lithium-ion battery recycling - Reductive ammonia leaching of metals from cathode scrap by sodium sulphite, Waste Manage., 60, 680-688.

[7] Chen, Y., Liu, N., Hu, F., Ye, L., Xi, Y., and Yang, S., 2018, Thermal treatment and ammoniacal leaching for the recovery of valuable metals from spent lithium-ion batteries, Waste Manage., 75, 469-475.

[8] Zou, H., Gratz, E., Apelian, D., and Wang, Y., 2013, A novel method to recycle mixed cathode materials for lithium-ion batteries, Green Chem., 15 (5), 1183-1191.

[9] Chen, W.S., and Ho, H.J., 2018, Recovery of valuable metals from lithium-ion batteries NMC cathode waste materials by hydrometallurgical methods, Metals, 8 (5), 3211.

[10] Joulié, M., Laucournet, R., and Billy, E., 2014, Hydrometallurgical process for the recovery of high value metals from spent lithium nickel cobalt aluminum oxide-based lithium-ion batteries, $J$. Power Sources, 247, 551-555.

[11] Muzayanha, S.U., Yudha, C.S., Nur, A., Widiyandari, H., Haerudin, H., Nilasary, H., Fathoni, F., and Purwanto, A., 2019, A fast metals recovery methods for the synthesis of lithium nickel cobalt aluminum oxide material from cathode waste, Metals, 9(5), 615.

[12] Li, L., Bian, Y., Zhang, X., Guan, Y., Fan, E., Wu, F., and Chen, R., 2018, Process for recycling mixedcathode materials from spent lithium-ion batteries and kinetics of leaching, Waste Manage., 71, 362371.

[13] Purwani, M.V., and Muzakky, 2019, Optimization and kinetics of zirconium oxychloride (ZOC) dissolution using $\mathrm{HNO}_{3}$, Indones. J. Chem., 19 (4), 928-935.

[14] Gao, W., Song, J., Cao, H., Lin, X., Zhang, X., Zheng, X., Zhang, Y., and Sun, Z., 2018, Selective recovery of valuable metals from spent lithium-ion batteries - Process development and kinetics evaluation, J. Cleaner Prod., 178, 833-845.

[15] Nayl, A.A., Elkhashab, R.A., Badawy, S.M., and ElKhateeb, M.A., 2017, Acid leaching of mixed spent 
Li-ion batteries, Arabian J. Chem., 10 (Suppl. 2), S3632-S3639.

[16] Zheng, Y., Long, H.L., Zhou, L., Wu, Z.S., Zhou, X., You, L., Yang, Y., and Liu, J.W., 2016, Leaching procedure and kinetic studies of cobalt in cathode materials from spent lithium-ion batteries using organic citric acid as leachant, Int. J. Environ. Res., 10 (1), 159-168.

[17] Chen, X., Xu, B., Zhou, T., Liu, D., Hu, H., and Fan, S., 2015, Separation and recovery of metal values from leaching liquor of mixed-type of spent lithiumion batteries, Sep. Purif. Technol., 144, 197-205.

[18] Kim, E., Kim, M., Lee, J., Jeong, J., and Pandey, B.D., 2011, Leaching kinetics of copper from waste printed circuit boards by electro-generated chlorine in $\mathrm{HCl}$ solution, Hydrometallurgy, 107 (3-4), 124-132.

[19] Meshram, P., Pandey, B.D., and Mankhand, T.R., 2015, Hydrometallurgical processing of spent lithium-ion batteries (LIBs) in the presence of a reducing agent with emphasis on kinetics of leaching, Chem. Eng. J., 281, 418-427.

[20] Meshram, P., Pandey, B.D., and Mankhand, T.R., 2015, Recovery of valuable metals from cathodic active material of spent lithium-ion batteries: Leaching and kinetic aspects, Waste Manage., 45, 306-313.

[21] Zhuang, L., Sun, C., Zhou, T., Li, H., and Dai, A., 2019, Recovery of valuable metals from $\mathrm{LiNi}_{0.5} \mathrm{Co}_{0.2} \mathrm{Mn}_{0.3} \mathrm{O}_{2}$ cathode materials of spent $\mathrm{Li}-$ ion batteries using mild mixed acid as leachant, Waste Manage., 85, 175-185.

[22] Demirkiran, N., and Künkül, A., 2007, Dissolution kinetics of ulexite in perchloric acid solutions, Int. J. Miner. Process., 83 (1-2), 76-80.

[23] Li, G., Rao, M., Jiang, T., Huang, Q., and Peng, Z., 2011, Leaching of limonitic laterite ore by acidic thiosulfate solution, Miner. Eng., 24 (8), 859-863.

[24] Zhang, X., Cao, H., Xie, Y., Ning, P., An, H., and You, H., 2015, A closed-loop process for recycling $\mathrm{LiNi}_{1 / 3} \mathrm{Co}_{1 / 3} \mathrm{Mn}_{1 / 3} \mathrm{O}_{2}$ from the cathode scraps of lithium-ion batteries: Process optimization and kinetics analysis, Sep. Purif. Technol., 150, 186-195.

[25] Espiari, S., Rashchi, F., and Sadrnezhaad, S.K., 2006, Hydrometallurgical treatment of tailings with high zinc content, Hydrometallurgy, 82 (1-2), 54-62.

[26] Ebrahimzade, H., Reza, G., and Mahin, K., 2018, Leaching kinetics of valuable metals from waste $\mathrm{Li}$ ion batteries using neural network approach, $J$. Mater. Cycles Waste Manage., 20, 2117-2129. 